\title{
Climate Change Fuel Cell Program
}

\author{
200 kW - PC25C Fuel Cell Power Plant \\ for the \\ St.-Agnes-Hospital, Bocholt, Germany
}

\section{Final Report}

Reporting Period: November 2, 2000 until January 2, 2002

Dipl.-Ing. Knut Stahl (M.S.)

January 2002

DOE Award Number: DE-FG26-99FT40602

T.B.E. - Technische Beratung Energie $\mathrm{GmbH}$

Theodor-Heuss-Str. 3-5

47167 Duisburg

GERMANY 


\section{Disclaimer}

This report was prepared as an account of work sponsored by an agency of the United States Government. Neither the United States Government nor any agency thereof, nor any of their employees, makes any warranty, express or implied, or assumes any legal liability or responsibility for the accuracy, completeness, or usefulness of any information, apparatus, product, or process disclosed, or represents that its use would not infringe privately owned rights. Reference herein to any specific commercial product, process, or service by trade name, trademark, manufacture, or otherwise does not necessarily constitute or imply its endorsement, recommendation, or favoring by the United States Government or any agency thereof. 


\section{Abstract}

Since the beginning of the Year 2001, the Saint-Agnes-Hospital in Bocholt, Germany, operates a phosphoric acid fuel cell (PAFC) to provide the base load of electrical power as well as heat in Winter and air conditioning in Summer. The project was made possible by federal funding from the U.S. Department of Energy as well as by a strategic alliance with the local utility company, the Bocholter Energie- und Wasserversorgung $\mathrm{GmbH}$ (BEW), and with the gas supplier of BEW, the Thyssengas $\mathrm{GmbH}$. The fuel cell power plant is combined with an absorption chiller. It is highly efficient and has an excellent power to heat ratio. The operation during the first Year went smoothly and nearly free of trouble. 


\section{Table of Contents}

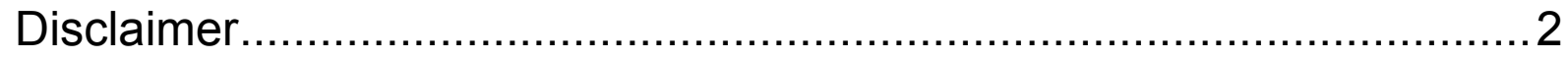

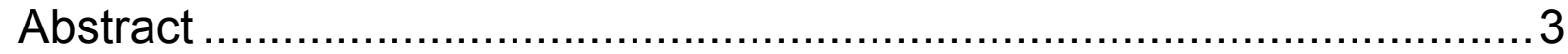

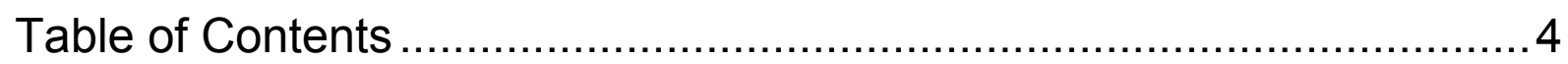

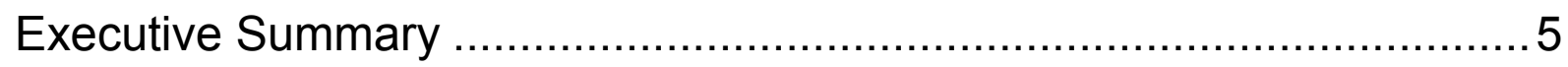

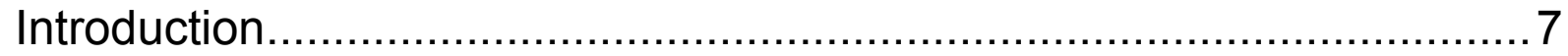

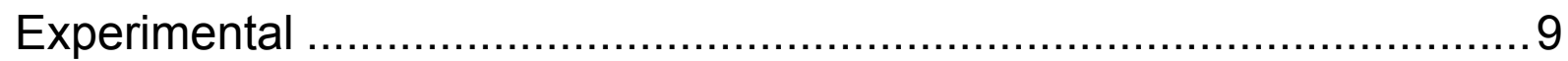

Results and Discussion ............................................................... 10

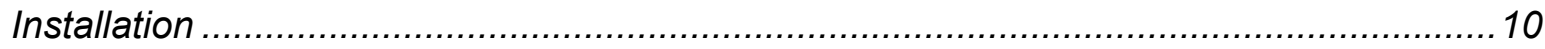

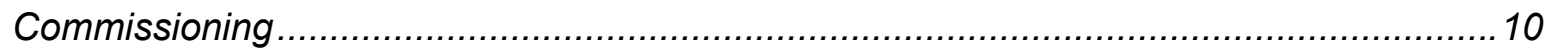

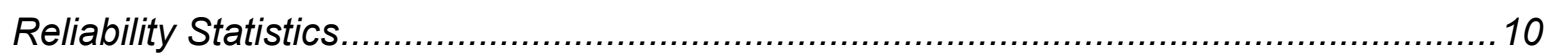

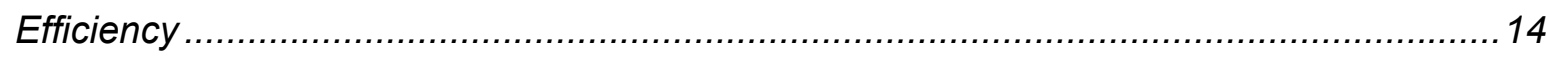

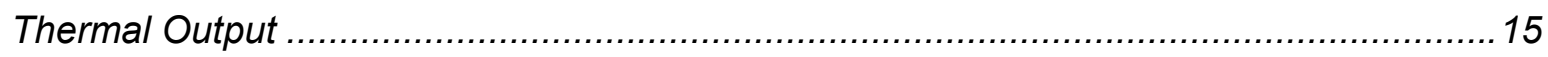

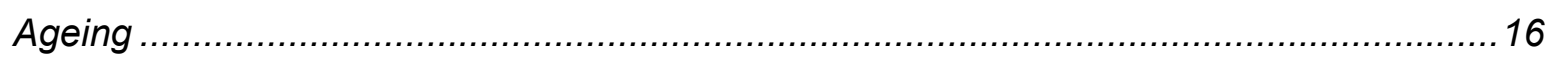

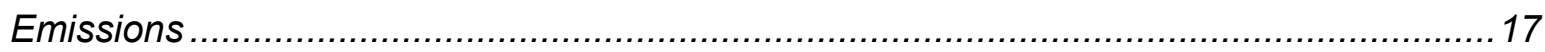

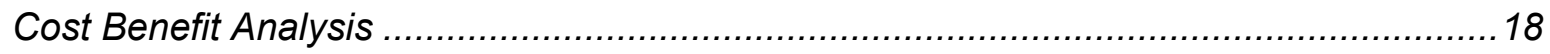

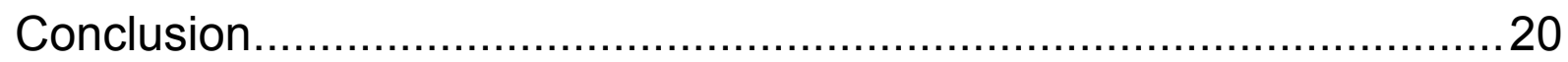

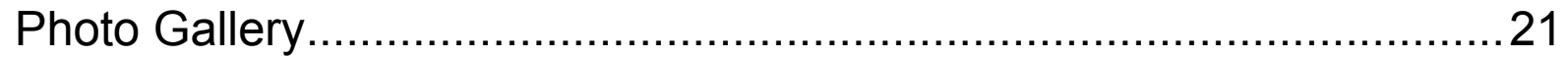

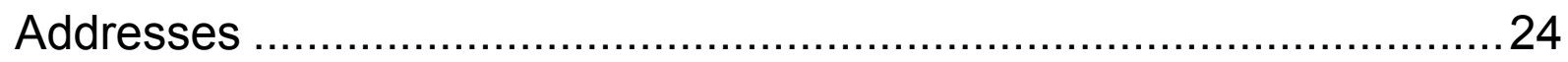




\section{Executive Summary}

By the end of the Year 2000, the Saint-Agnes-Hospital, a 500-bed hospital in Bocholt, Germany, has installed and operated a PC25C phosphoric acid fuel cell power plant made by UTC Fuel Cells. This product was chosen because its technical data met the demand of the hospital, and because it is the only fuel cell product that is beyond demonstrator status.

The hospital already operates two gas engine cogeneration units since 1990, allowing direct comparison of the two competing technologies.

The fuel cell's investment cost is 4 to 5 times higher than for a comparable gas engine cogeneration unit. Hospitals in Germany are financed by the general health insurance system, i. e. by every citizen, and cost effectiveness is a must. The fuel cell installation was made possible only by a strategic alliance with the local utility company and the major regional gas supplier, the Bocholter Energie- und Wasserversorgung $\mathrm{GmbH}(\mathrm{BEW})$ and the Thyssengas $\mathrm{GmbH}$, as well as by federal funding from the U.S. Department of Energy. This partnership between end user, energy suppliers, and (initially) government institutions is a model for further projects and will be one important way to introduce fuel cell technology into the market.

The fuel cell has achieved about 8,000 hours of operation during the first Year. Only two shutdowns have occurred due to equipment failure. The power plant availability factor was $96.7 \%$, and a mean time between forced outages (MTBFO) greater than 2,500 hours has been demonstrated, surpassing the gas engine cogeneration units.

The electrical efficiency of the PC25C fuel cell is significantly higher than of the gas engine cogeneration units. The fuel cell has achieved an electrical efficiency of almost $40 \%$, and a total fuel utilization of $84 \%$. The combined operation with the absorption chiller has been proven in Summer, enabling better heat utilization in times of low heat demand.

Phosphoric acid fuel cells show a loss of voltage over time, resulting in a performance degradation. The voltage loss during the first Year of operation was within the expected range, and the expected useful life of the power plant of 5 to 7 Years has so far been confirmed by the operation results.

The fuel cell is virtually emission-free and produces no local pollutants that cause smog and acid rain. Compared to the power plant mix in Germany, the PC25C fuel cell saves roughly 500 tons of carbon dioxide per Year.

The fuel cell at the St.-Agnes-Hospital in Bocholt has generated only a small profit during the first Year of operation, due to relatively low power prices after the recent power market deregulation in Germany. Still, it has met the cost reduction requirement of the hospital. Investment cost as well as service cost have not exceeded the projected figures. 
The fuel cell receives much public attention, especially from other hospitals throughout the country. The power plant of the St.-Agnes-Hospital in Bocholt is the third fuel cell in service at a hospital in Germany. The project has been presented on numerous occasions in articles, exhibitions, and seminars. It is expected that similar applications will follow in the near future.

Fuel cells are well suitable for distributed generation, as they offer a wide variety of size, power, system temperatures, operation characteristics, and fuels. The PC25C has already proven that fuel cell power plants can outperform other cogeneration technologies in terms of good fuel efficiency, low emissions and high reliability. Given the cost targets will be met, fuel cells will play a major role in the energy supply of the future. 


\section{Introduction}

The St.-Agnes-Hospital in Bocholt provides medical services for the city of Bocholt and the mostly rural region around it. Bocholt, a city of some 70,000 inhabitants, is located in the far west of Germany, close to the Dutch border. The hospital has a capacity of 496 beds for stationary patients, and in the last Year, almost 20,000 people received medical treatment.

Today, the St.-Agnes-Hospital comprises the following medical departments:

- General and visceral surgery

- Accident surgery

- Vascular surgery

- Internist Department I: Cardiology and intensive medical care

- Internist Department II: Gastroenterology and onkology

- Urology

- Gynecology and obstetrics

- Pediatrics

- Department of anesthesia and intensive surgical medical care

- Department of radiology diagnostics

- Radiotherapy

- Nuclear medicine

- Pathology

Hospitals have a high energy demand and are well suitable for the combined generation of power and heat (cogeneration). Consequently, the St.-Agnes-Hospital has installed and operated two gas engine cogeneration units since the Year 1990. The gas engines generate a total electrical power of $428 \mathrm{~kW}(289 \mathrm{~kW}$ and $139 \mathrm{~kW})$ and are capable of providing $733 \mathrm{~kW}$ (491 kW and $242 \mathrm{~kW}$ ) of heat at the same time. Additional peak boilers and steam boilers deliver a maximum of around $5 \mathrm{MW}$ of heat.

Recently, new medical departments with high power demand, such as radiotherapy and nuclear medicine were added. Therefore, an expansion of the hospital's power supply became necessary. The hospital's technical director started to focus on the emerging fuel cell technology.

After an economic evaluation, the PC25C fuel cell made by UTC Fuel Cells (formerly International Fuel Cells / ONSI Corporation) in South Windsor, Connecticut, turned out to be the only product that is commercially available. In terms of a hospital as an end user, 'commercially available' means that the contractual conditions, warranties and service plans are similar to other well established cogeneration products, such as gas engine cogeneration units. However, although the higher efficiency of the fuel cell gives it some economic advantage over the gas engine, the investment cost was 4 to 5 times higher than for a cogeneration unit of similar power. 
The St.-Agnes-Hospital approached their local utility company, the "Bocholter Energie- und Wasserversorgung GmbH" (BEW) for assistance. BEW showed interest to support a fuel cell installation in their region, but their contribution was limited due to economic uncertainties after the liberalization / deregulation of the German power market in 1998.

Subsequently, the gas supplier of BEW, the Thyssengas GmbH in Duisburg, was also contacted. Thyssengas, a major German gas company, is well known for its fuel cell activities, which includes in-house testing and support of demonstration projects of fuel cell power plants throughout the country. Thyssengas had operated a PC25A power plant from 1992 to 1997.

In 1998, BEW and Thyssengas agreed to provide financial assistance to the St.-AgnesHospital, leaving an investment share for the hospital that will lead to similar power generation cost (cost per kilowatt-hour) than with a conventional cogeneration unit. The investment share for the hospital is still nearly twice as high as for a similar gas engine cogeneration unit, but the higher efficiency of the fuel cell will level this out over the projected lifetime of 15 Years. An agreement was made between the St.-Agnes-Hospital, BEW, and Thyssengas, to share the cost for a major cell stack and power plant overhaul as well, which is expected to become necessary after 5 to 7 Years.

All necessary tasks to purchase, install and maintain the fuel cell unit were assigned to the T.B.E. GmbH in Duisburg, an engineering company and $100 \%$ subsidiary of Thyssengas.

A price increase of about $30 \%$ for the PC25C, as announced by International Fuel Cells early 1999, nearly stopped all activities. However, after a meeting with a representative for the "Climate Change Fuel Cell Program", T.B.E. applied for federal funding on behalf of the St.Agnes-Hospital. This federal funding, if granted to the St.-Agnes-Hospital, would more or less equal out the price increase by the fuel cell manufacturer.

Federal funding was indeed granted in July 1999, and the fuel cell was purchased from UTCFC (IFC) at the same time. Delivery to site was scheduled for October 2000, and the power plant installation was completed by the end of December 2000. At the same time, Thyssengas changed the natural gas quality on site to a source with a low nitrogen content, because nitrogen-rich fuel gas negatively affects the lifetime of phosphoric acid fuel cells.

The fuel cell power plant is in operation since January 2001 and has achieved about 8,000 load hours during the first Year. 


\section{Experimental}

The following paragraph outlines the project goals of the PC25C fuel cell installation at the St.-Agnes-Hospital in Bocholt.

Fuel cells are widely seen as an alternative to gas engines for the combined generation of power and heat (cogeneration). Cogeneration in itself saves energy and reduces local emissions, and the application of fuel cells in this market will further improve these features.

Hospitals are well suitable for the combined generation of power and heat (cogeneration) and will become an interesting market for fuel cell products, given that demonstration projects prove that the technology has reached a certain level of maturity.

The PC25C power plant at the St.-Agnes-Hospital in Bocholt shall prove:

- Fuel cells generate power and heat with a higher electrical efficiency and with significantly lower local emissions than any other technology.

- The combination with the absorption chiller leads to an excellent total fuel utilization throughout the whole Year.

- The power plant reliability is superior compared to the two existing gas engine cogeneration units.

- The PC25C has reached a level of maturity which permits operation and regular maintenance being done by the hospital's technical staff.

- Operation and maintenance efforts do not exceed the standards set by other cogeneration technologies.

- Fuel cells are cost effective, except for the higher investment cost. 


\section{Results and Discussion}

The following paragraphs provide details about the first Year of operation of the fuel cell power plant at the St.-Agnes-Hospital in Bocholt. They focus on power plant reliability, costs and savings, and on operation and maintenance issues.

\section{Installation}

The power plant was received on site on November 2, 2000. Several transportation damages on the container hull were noted immediately, and had to be repaired on site. All power plant subsystems were thoroughly tested and checked, a loose fan wheel and a failed igniter had to be fixed. However, no major damages were found, and the unit was prepared for operation in December 2000.

Site works, such as plumbing and cabling, were carried out simultaneously. The connections to the fuel cell power plant were completed in December 2000, but modifications to the hospital's heating system continued until Summer 2001 to improve the heat recovery from the fuel cell.

\section{Commissioning}

The PC25C power plant was commissioned early January 2001, and the first start-up successfully took place on January 16, 2001. Rated power was achieved one day later only. The start-up process went essentially without problems, only one shutdown occurred due to wrong settings of a motor starter.

The PC25C fuel cell power plant is not built according to European or German technical standards; therefore, an approval by an authorized German inspection agency is necessary. This includes inspection of pressure vessels at the manufacturer's facilities as well as testing the function of safety equipment of the fuel cell power plant during operation on site. This site test was carried out on January 22, 2001, resulting in a power plant shutdown as planned. Due to outstanding works on the gas supply line (installation of new flow meters), the restart was postponed by three weeks.

\section{Reliability Statistics}

To determine the reliability statistics, definitions are used that are published by the Gas Technology Institute (GTI) in Des Plaines, Illinois. GTI is an independent, not-for-profit technology organization that provides products, programs, information and services related to energy and the environment, with a focus on the production, delivery, use and environmental aspects of natural gas. 


\section{Definitions:}

"There are various ways to measure reliability. In power generation systems, key measures of performance are availability and various maintenance-related indices. The following graphic illustrates different reliability categories for a given period of time (e.g., one year). A power generation system is characterized - depending on its operating state - to be in one of these conditions."

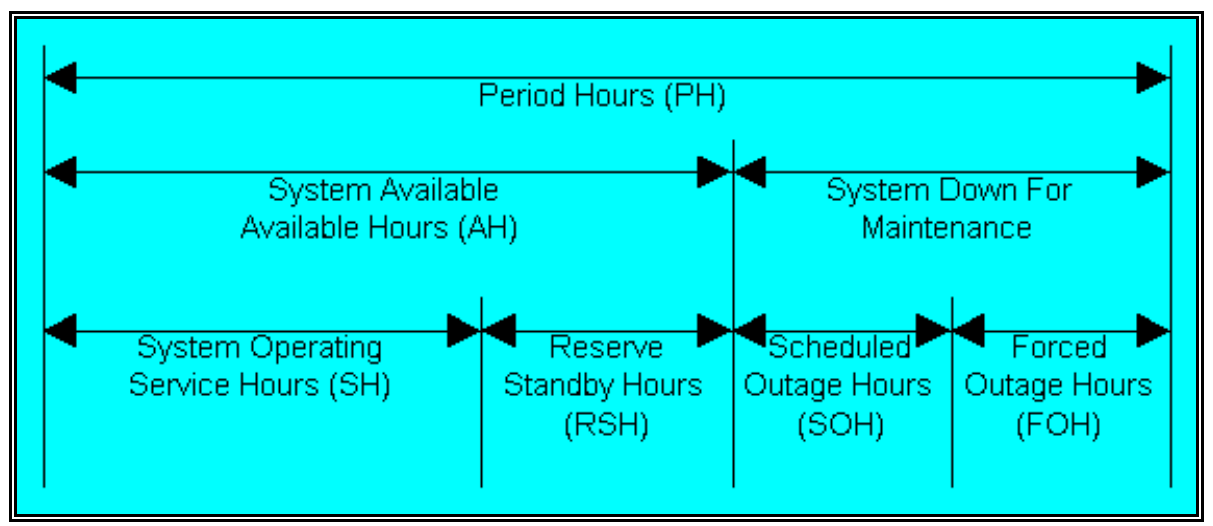

"A number of performance indices can be calculated based on operational and maintenance data."

\begin{tabular}{|c|c|}
\hline Reliability Performance Indices & Formula \\
\hline $\begin{array}{l}\text { Period of Demand (POD): } \\
\text { Measures the time the unit was planned to oper- } \\
\text { ate. }\end{array}$ & $P O D=P H-R S H-S O H$ \\
\hline $\begin{array}{l}\text { Availability Factor (AF, \%): } \\
\text { Measures, on a percent basis, the unit's "could } \\
\text { run" capability. Impacted by planned and un- } \\
\text { planned maintenance. }\end{array}$ & $A F=\frac{(P H-S O H-F O H) \times 100}{P H}$ \\
\hline $\begin{array}{l}\text { Forced Outage Rate (FOR, \%): } \\
\text { Measures portion of downtime due to unplanned } \\
\text { factors. }\end{array}$ & $F O R=\frac{F O H \times 100}{S H+F O H}$ \\
\hline $\begin{array}{l}\text { Scheduled Outage Factor (SOF, \%): } \\
\text { Measures percent of time set aside for planned } \\
\text { maintenance. }\end{array}$ & $S O F=\frac{S O H \times 100}{P H}$ \\
\hline $\begin{array}{l}\text { Service Factor (SF, \%): } \\
\text { Percent of total period hours the unit is on-line- } \\
\text { varies due to site-related or economic factors. }\end{array}$ & $S F=\frac{S H \times 100}{P H}$ \\
\hline $\begin{array}{l}\text { Mean Time Between Forced Outages } \\
\text { (MTBFO): Measures the nominal time between } \\
\text { unscheduled forced outages. }\end{array}$ & $M T B F O=\frac{S H}{\# \text { ForcedOutages }}$ \\
\hline $\begin{array}{l}\text { Mean Down Time (MDT): } \\
\text { Measures the nominal duration the unit is down } \\
\text { during maintenance events. }\end{array}$ & $M D T=\frac{S O H+F O H}{\# \text { ForcedOutages }+\# \text { PlannedO }}$ \\
\hline
\end{tabular}

(Source: http://www.gri.org/pub/solutions/dg/rel_metrics.html) 


\section{Events causing power plant shutdown:}

To date (02/01/2002), four shutdowns have occurred. Only two of these shutdowns are related to equipment failure, and both were caused by the same fault (bad wiring / soldering on a connector of the fuel cell controller's UPS), which was not identified immediately.

The other two shutdowns were caused by:

1) Shutdown due to safety equipment testing by local authorities (power to the feedwater pump was manually disabled, and the power plant shut down due to low water level in the steam accumulator).

2) Shutdown during the attempt to operate in parallel with the emergency power diesel generator, after a grid outage.

\begin{tabular}{|l|r|r|r|r||}
\hline Description / Event & Date & Loadtime & Run hrs & S/D hrs \\
\hline First start-up & $\begin{array}{c}01 / 16 / 01 \\
19: 07\end{array}$ & 130 & & \\
\hline Shutdown due to safety equipment testing, & $01 / 22 / 01$ & 268 & 138 & \\
witnessed by a local inspection agency & $13: 07$ & & & \\
\hline Restart & $02 / 12 / 01$ & 268 & & \\
& $16: 07$ & & & \\
\hline Shutdown due to parallel run with emer- & $02 / 28 / 01$ & 643 & 375 & \\
gency diesel genset after a grid outage on & $07: 36$ & & & \\
site & & & & \\
\hline Restart & $03 / 01 / 01$ & 643 & & \\
\hline Loss of logic power supply during a grid & $06 / 17 / 01$ & 3228 & 2588 & \\
outage on site, failure of fuel cell UPS & $13: 50$ & & & \\
\hdashline Restart & $06 / 21 / 01$ & 3228 & & \\
\hline Loss of logic power supply during a grid & $07 / 18 / 01$ & 3872 & & \\
outage on site, failure of fuel cell UPS & $15: 47$ & & & \\
\hdashline Restart & $07 / 24 / 01$ & 3872 & & \\
\hline Operation since 07/24/01, continued. & $01 / 02 / 02$ & 7758 & 3886 & \\
\hline
\end{tabular}


Reliability Statistics - Results:

\begin{tabular}{|l|r||}
\hline Reliability Performance Indices & (January 2, 2002) \\
\hline Period Hours, PH & $8419 \mathrm{hrs}$ \\
\hline Scheduled Outage Hours, SOH & $0 \mathrm{hrs}$ \\
\hline Forced Outage Hours, FOH & $278 \mathrm{hrs}$ \\
\hline Reserve Standby Hours, RSH & $507 \mathrm{hrs}$ \\
\hline System Available - Available Hours, AH & $8141 \mathrm{hrs}$ \\
\hline System Operating Service Hours, SH & $7634 \mathrm{hrs}$ \\
\hline Period of Demand, POD & $7912 \mathrm{hrs}$ \\
\hline Availability Factor, AF & $96.7 \%$ \\
\hline Forced Outage Rate, FOR & $3.5 \%$ \\
\hline Scheduled Outage Factor, SOF & $0.0 \%$ \\
\hline Service Factor, SF & $90.7 \%$ \\
\hline Mean Time Between Forced Outages, MTBFO & $2545 \mathrm{hrs}$ \\
\hline Mean Down Time, MDT & $70 \mathrm{hrs}$ \\
\hline
\end{tabular}

\section{Other Events:}

The reformer start burner, which preheats the reformer catalyst during a power plant start to its operating temperature of around $815^{\circ} \mathrm{C}(1500 \mathrm{DegF})$, frequently fails to ignite. The ignition problem is caused by condensate that forms in the start burner gas line during normal power plant operation. Prior to each start, the start burner gas line has to be disassembled to remove trapped water, followed by a burner test. During the next scheduled maintenance, T.B.E. will modify the gas piping inside the fuel cell power plant such that water accumulation is prevented.

The power plant runs fully automatic and unattended. Once a week, it is inspected by the operator. Air filters are exchanged by the operator every 2,000 hours or earlier, as necessary. The internal water treatment system of the fuel cell power plant that supplies ultra-pure water for the fuel processor has been serviced after 4,500 hours of operation. Some adjustments of valves, thermostats, and power plant controller parameters are required from time to time. All these activities are done with the power plant in operation.

The annual maintenance is now due and will be carried out as soon as the weather conditions permit. 


\section{Efficiency}

The St.-Agnes-Hospital operates two gas engine cogeneration units in a similar power range like the PC25C fuel cell, which allows direct comparison. The following table summarizes the relevant technical data:

\begin{tabular}{||l|c|c|c||}
\hline \hline & CoGen 1 & CoGen 2 & Fuel Cell \\
\hline Manufacturer & MDE / MAN & MDE / MAN & UTCFC / PC25C \\
\hline El. Power $[\mathrm{kW}]$ & 289 & 139 & 200 \\
\hline Rec. Heat $\quad[\mathrm{kW}]$ & 491 & 242 & 220 \\
\hline Fuel Cons. $\quad[\mathrm{kW}]$ & 889 & 417 & 500 \\
\hline Electrical Efficiency & $32.5 \%$ & $33.3 \%$ & $40 \%$ \\
\hline Power-to-Heat Ratio & $\sim 0.6$ & $\sim 0.6$ & $\sim 0.9$ \\
\hline Thermal Efficiency & $55.3 \%$ & $58.1 \%$ & $44 \%$ \\
\hline Total Fuel Utilization & $87.8 \%$ & $91.4 \%$ & $84.0 \%$ \\
\hline \hline
\end{tabular}

It should be noted that both gas engine cogeneration units were installed in 1990, and gas engines have improved since then. Nevertheless, the electrical efficiency of the fuel cell power plant is significantly higher. To generate $1,000 \mathrm{kWh}$ of electricity in the gas engines, about $300 \mathrm{~m}^{3}$ of natural gas are required, while the fuel cell needs only about $250 \mathrm{~m}^{3}$.

The heat recovery systems of the gas engine cogeneration units are more efficient than the fuel cell's, a task for ongoing development in the future. The following paragraph provides more details about the heat losses, and suggests improvements.

The performance data are valid for new units only. The effects of time on the power plant performance are discussed in detail in a special section ("Ageing"). 


\section{Thermal Output}

The chart below depicts the fuel utilization of the PC25C fuel cell power plant at the St.Agnes-Hospital in Bocholt, based on measurements taken throughout the first Year of operation. Electrical power, high-grade heat and low-grade heat are metered on site, and the losses have been calculated based on temperature metering and manufacturer data for air and exhaust gas flow.

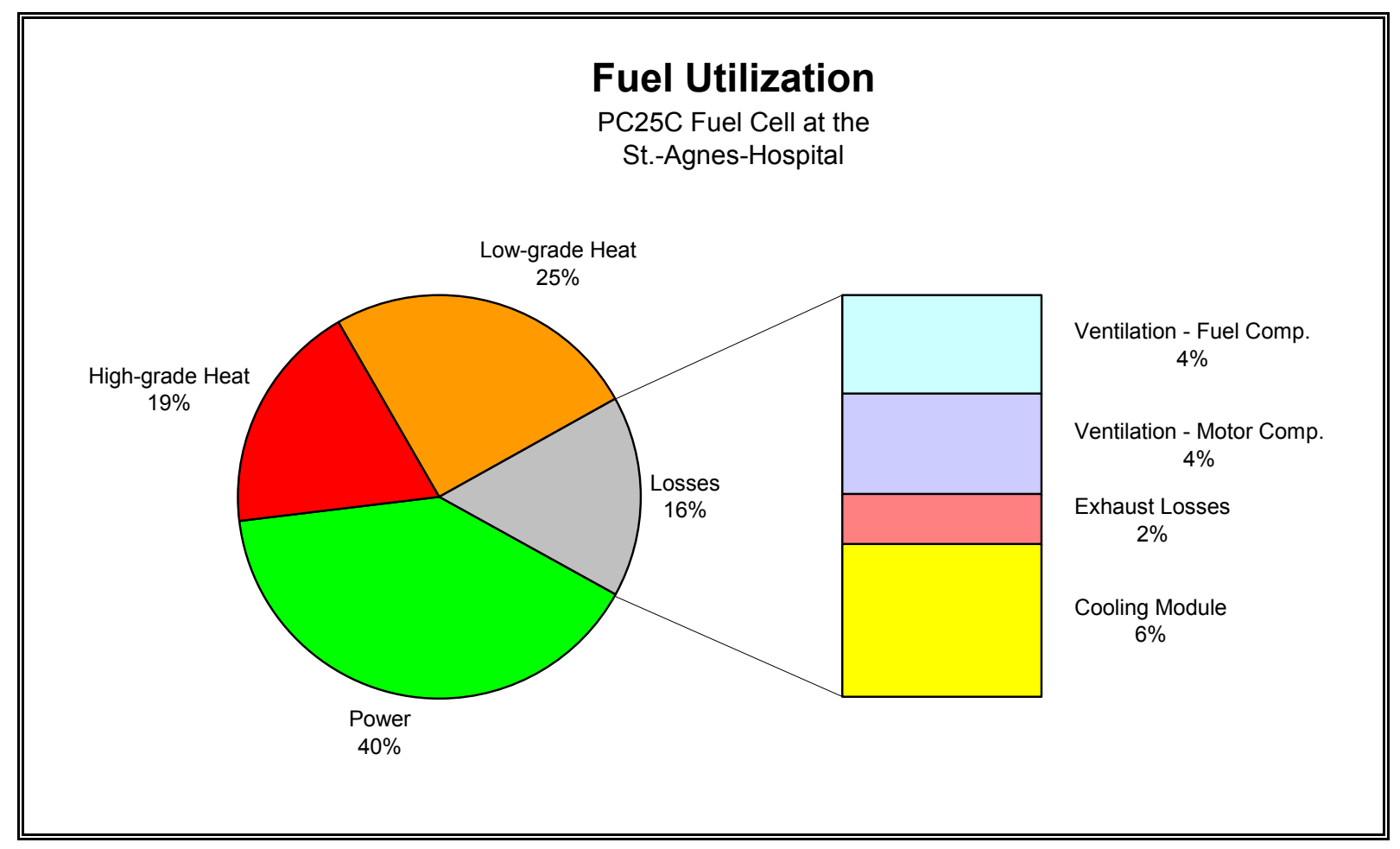

The power plant electrical efficiency is close to $40 \%$ (39.6\%), based on the lower heating value of the natural gas fuel. A total fuel utilization of $84 \%$ has been achieved. Efforts have been made to improve the low-grade heat recovery to prevent the cooling module turning on, which has occurred several times during the first months of operation.

The combined operation with the absorption chiller has been proven in Summer, enabling better heat utilization in times of low heat demand. After initial controller problems, the rated chiller output of more than $40 \mathrm{~kW}$ of cold water for air conditioning was achieved.

Ventilation losses of the fuel cell power plant are rather high due to the safety design, which requires an air flow high enough to prevent the formation of explosive gases inside the packaged unit. Other safety approaches may be considered, e. g. gas detectors. The warm ventilation air required for inverter cooling could then be ducted into the boiler house for combustion air preheating. 


\section{Ageing}

Fuel cells show a stack voltage degradation over time, resulting in a decline of the electrical efficiency. Manufacturer's product specifications estimate an average electrical efficiency of $37 \%$ over the expected lifetime of the power plant. The following chart shows the stack voltage degradation over time of the fuel cell power plant at the St.-Agnes-Hospital in Bocholt during the first Year of operation (2001):

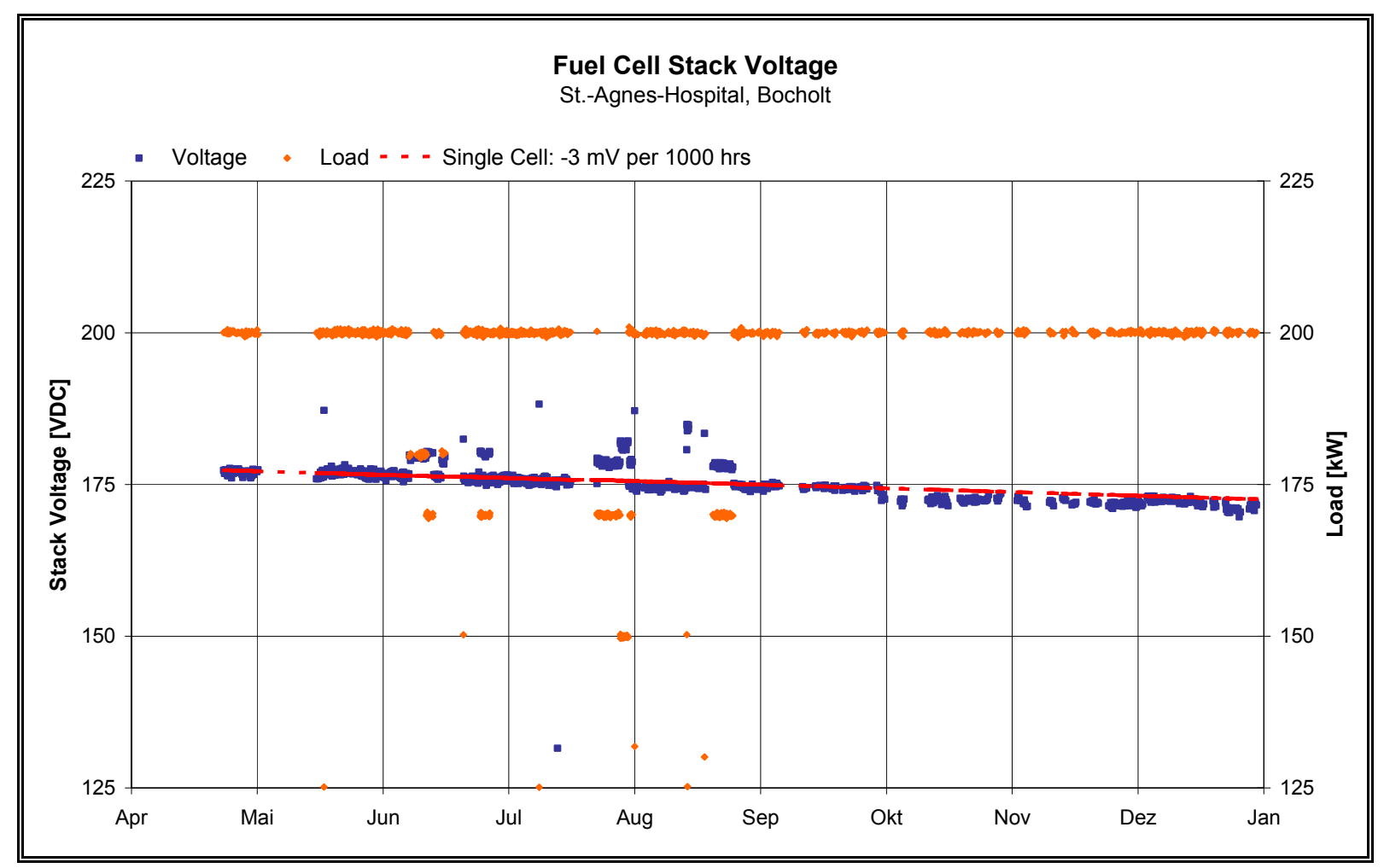

The stack voltage (blue dots) shows a degradation of about $-3 \mathrm{mV}$ per single cell every 1000 hours (red trend line). The cell stack consists of 272 single cells, so a total voltage loss of slightly more than $0.8 \mathrm{VDC}$ every 1000 hours is expected, or 6.5 VDC per Year. This result matches literature data, e. g. DOE's “Fuel Cell Handbook, 1998” (DOE/FETC-99/1076).

After the first start-up in January 2001, the stack voltage was around 178 VDC. If the degradation remains linear, the stack voltage will drop below 150 VDC after 4 to 5 Years (150 VDC is the low voltage limit of the inverter). Operation at part load may continue for another two Years, until a stack overhaul is inevitable.

Up to now, the expected stack overhaul after 5 to 7 Years is confirmed by the operation results. Still, ongoing development is required to minimize the voltage degradation in the future. 


\section{Emissions}

The following chart depicts the local emissions of carbon monoxide (CO) and nitrogen oxides $\left(\mathrm{NO}_{\mathrm{X}}\right)$ of the PC25C power plant at the St.-Agnes-Hospital in Bocholt, compared to the two existing gas-engine cogeneration units, and compared to the limits set by the "TA Luft '86" (German Clean Air Act, 1986).

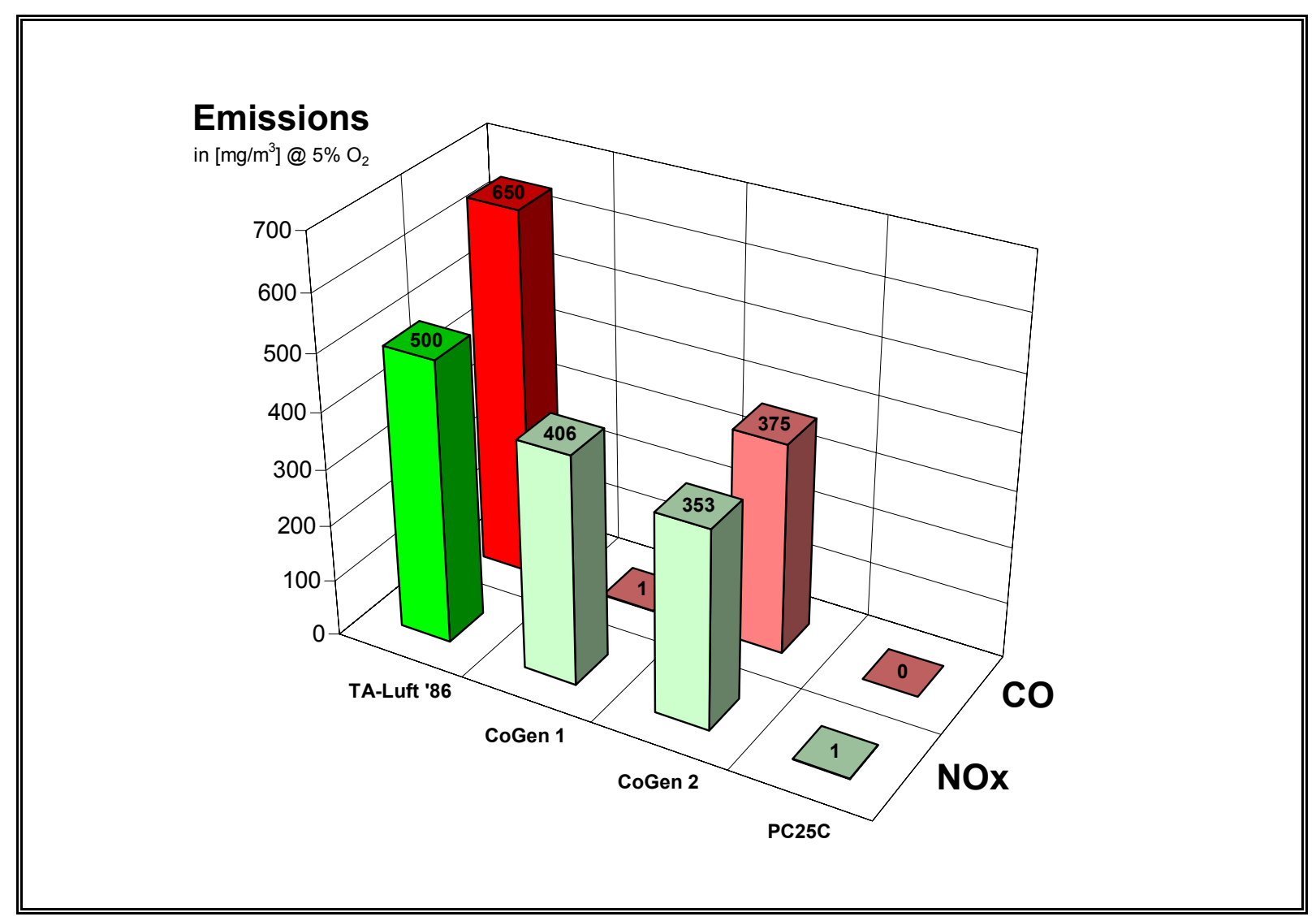

As expected, the emissions of $\mathrm{NO}_{\mathrm{X}}$ and $\mathrm{CO}$ from the fuel cell power plant are almost undetectable. Also, no $\mathrm{SO}_{2}$ is formed, as the fuel cell operates on desulfurized natural gas.

Compared to the average power plant emissions in Germany, the fuel cell at the St.-AgnesHospital in Bocholt saves roughly 500 tons of carbon dioxide $\left(\mathrm{CO}_{2}\right)$ per Year. 


\section{Cost Benefit Analysis}

The following tables provide the economic data from the first Year of operation. All cost have been converted into U.S. Dollars, based on the exchange rate of $1 \mathrm{US} \$=1.80 \mathrm{DM}$, which was fixed when the Contract of Sale became effective in July, 1999.

\begin{tabular}{||l|r||}
\hline \hline Activity & \multicolumn{1}{|c|}{ Cost $^{\mathbf{1}}$} \\
\hline Investment & 882,000 \\
\hline Total Fuel Cell Plant Cost & 152,000 \\
Installation Cost & $\mathbf{1 , 0 3 4 , 0 0 0}$ \\
Total Investment & \\
\hline Funding & 357,000 \\
St.-Agnes-Hospital & 477,000 \\
Thyssengas & 200,000 \\
U.S. DOE & $\mathbf{1 , 0 3 4 , 0 0 0}$ \\
Total Funding & \\
\hline
\end{tabular}

The investment budget for the installation of the fuel cell power plant has not been exceeded.

The investment cost for the absorption chiller system as well as the cost for modifications of the hospital's heat distribution system were not included in the above figures, a total of more than 250,000 U.S. \$.

Operation cost and savings were calculated based on gas and power prices in April 2001:

- Electricity price, including taxes and fees: $\quad 0.091576$ U.S. \$ per kWh

- Gas price (HHV basis), including taxes and fees: 0.026938 U.S. \$ per kWh

\begin{tabular}{||l|r||}
\hline Cost and Savings $^{2}$ & \\
\hline Capital Cost (St.-Agnes-Hospital investment share only) & 39,000 \\
Fuel Cost & 121,000 \\
Operation and Maintenance Cost & 22,000 \\
Capital investment for power plant overhaul & 30,000 \\
Power and Heat Savings & 225,000 \\
Result & $\mathbf{1 2 , 0 0 0}$ \\
\hline
\end{tabular}

\footnotetext{
${ }_{1}^{1}$ excluding VAT (currently 16\%)

${ }^{2}$ including VAT
} 
Thanks to the commitment of all project partners, the fuel cell power plant generates no financial losses for the St.-Agnes-Hospital. Market deregulation and resulting low electricity prices have put severe pressure on the decision of the St.-Agnes-Hospital to install a fuel cell cogeneration plant. Recently, falling gas prices and rising electricity prices have eased the pressure. The rise of electricity prices due to an annual increase of the German ecology tax (about 0.3 U.S. Cents per Year until 2003) will further improve the results. Fuel cells with a heat recovery that achieves a fuel utilization of more than $80 \%$ are exempted from taxes on natural gas.

The investment required for a power plant overhaul after 5 to 7 Years remains uncertain for now. The oldest PC25C units in the field now reach about 5 Years in operation, and it is expected to obtain more reliable cost figures for a cell stack replacement and other necessary overhauls soon. Currently, an investment of up to U.S. $\$ 300,000$ is expected, which will be shared between the Thyssengas, BEW, and the St.-Agnes-Hospital. 


\section{Conclusion}

The PC25C fuel cell power plant at the St.-Agnes-Hospital in Bocholt has successfully completed its first Year of operation. Run time and performance data have met the forecast figures. The fuel cell receives much public attention, but its main purpose is to return the investment the St.-Agnes-Hospital has made.

The St.-Agnes-Hospital in Bocholt is now one of the first hospitals in Germany that operates a fuel cell power plant. Ten Years ago, they were also among the first hospitals to install gas engine cogeneration units, which are a normality in German hospitals today.

The fuel cell installation at the St.-Agnes-Hospital was made possible only by an alliance with gas and utility companies as well as by federal funding from the U.S. Government. This partnership between end user, energy supplier, and (initially) government institutions is a model for further projects and will be one important way to introduce the fuel cell technology into the market.

The PC25C is the first fuel cell product that is commercially available. It has proven that fuel cell power plants can outperform other cogeneration technologies in terms of good fuel efficiency, low emissions and high reliability. Other fuel cell technologies and products that are now emerging will be measured against the achievements of the PC25C fleet, resulting in a competition that will improve fuel cell products as a whole and, above all, reduce their cost.

In this new market, a variety of fuel cell products will evolve, which will match the variety of their customer's demand situations. Power and utility companies will offer fuel cell power to their customers, adding a variety of financing and contracting options. This diversity of products and solutions is the main advantage of distributed generation (based on fuel cells as well as other technologies), leading to intelligent, economical and ecological solutions for each individual energy demand profile.

Clean, efficient fuel cells cause no air pollution and save our energy resources, especially when they are used for distributed (co-)generation. Eventually, more and more fuel cells may operate on renewable energy sources, such as biogas or methanol, or even hydrogen that was produced by water, wind, or solar power. Whatever the power supply of the future will look like, fuel cells and distributed generation offer the flexibility to adapt to an ever-changing energy market. 


\section{Photo Gallery}

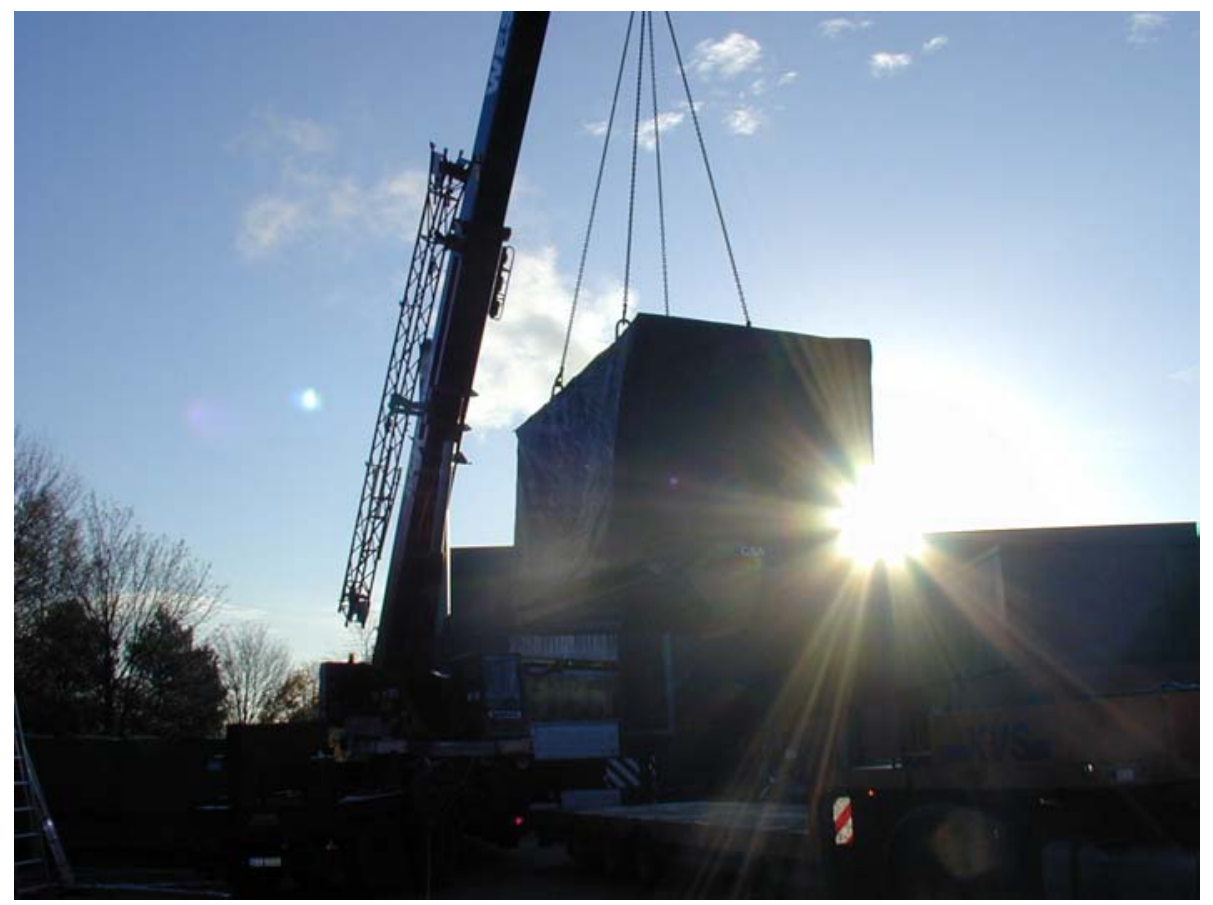

Fuel cell power plant arrives on site on November 2, 2000

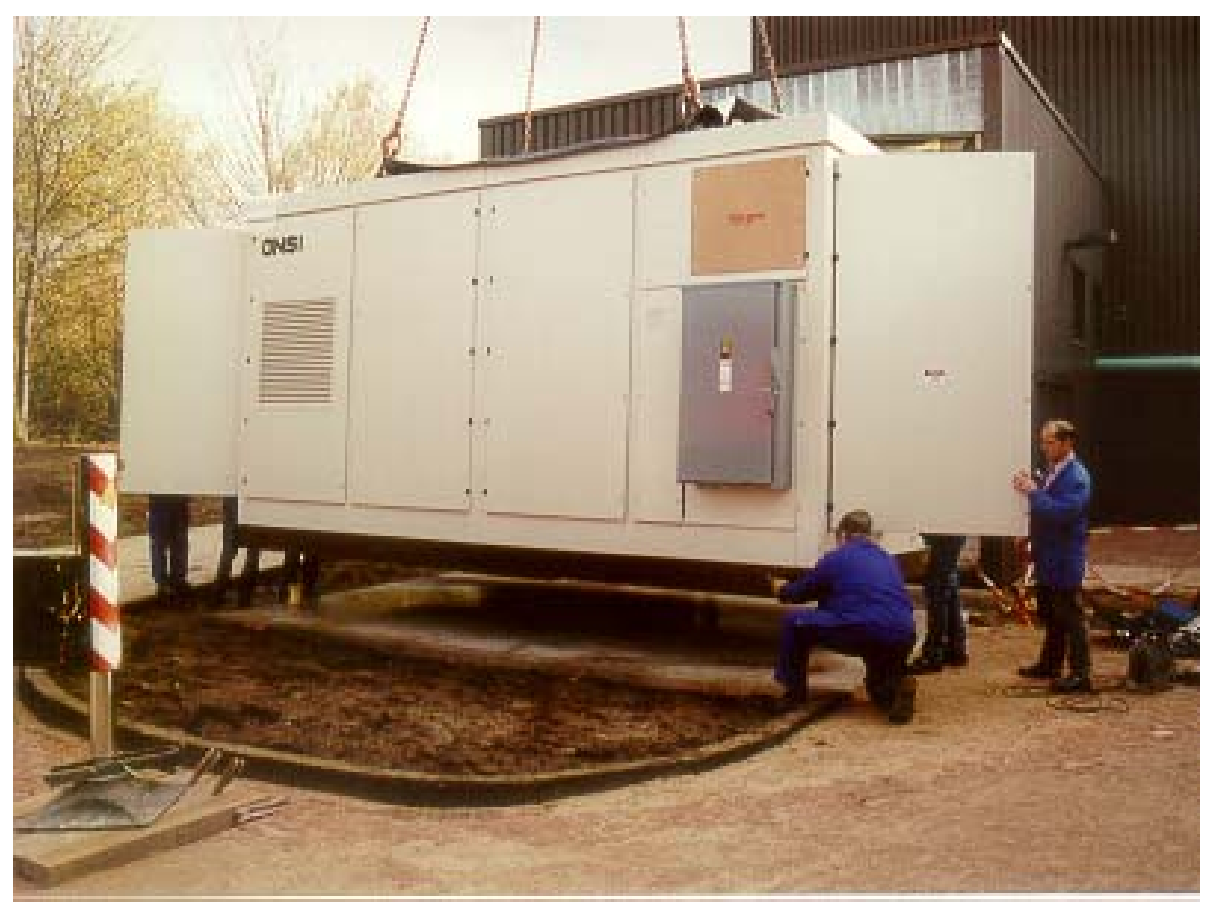

PC25C power plant unloading and installation 


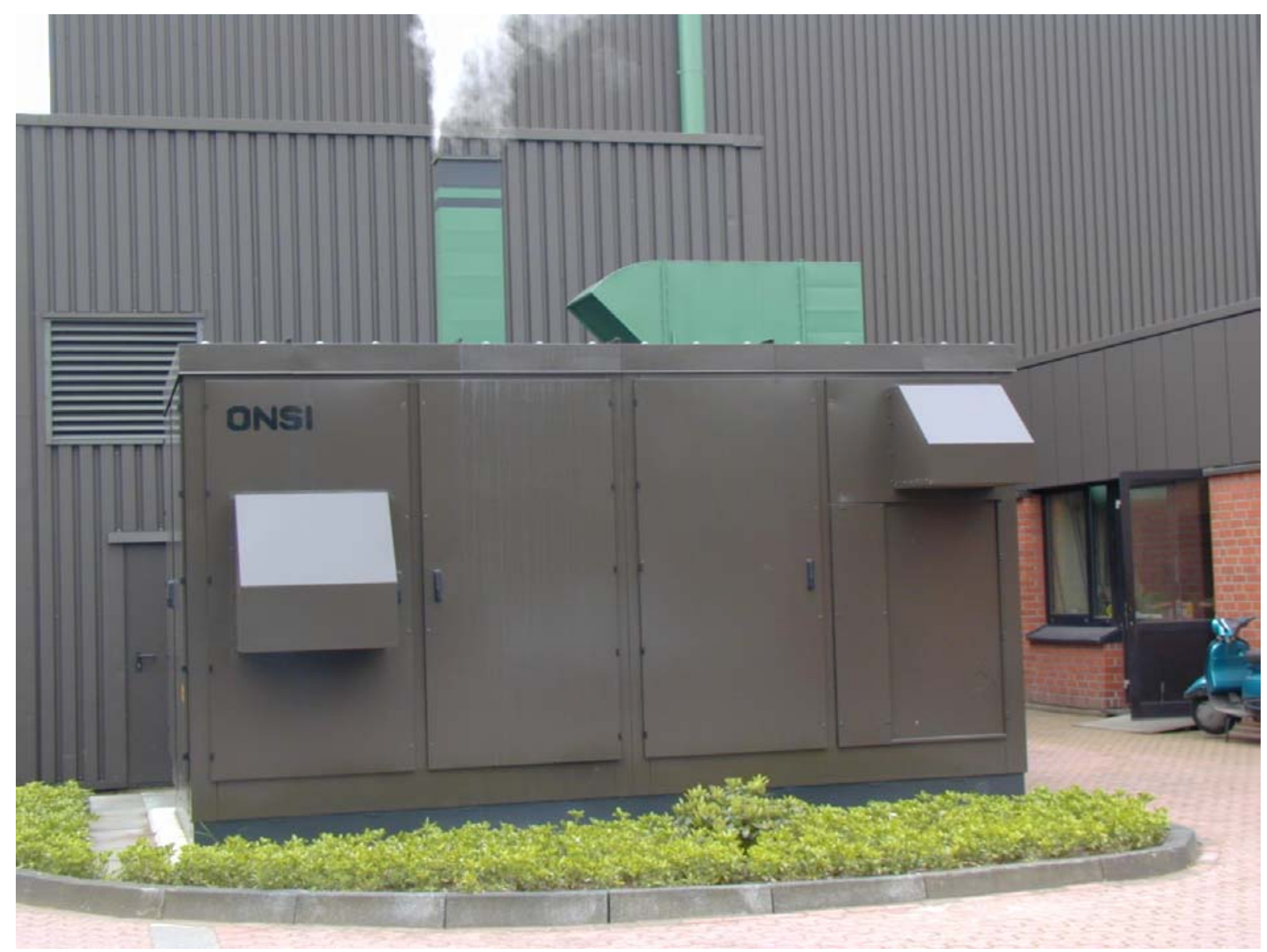

PC25C fuel cell power plant at the St.-Agnes-Hospital in full load operation

The vent exit silencer and the exhaust duct on top of the fuel cell container were added on site. The unit was painted to match the rest of the hospital buildings. Locks were installed on the container doors (instead of bolts) for easier access and higher security.

The manual power disconnect switch of the unit was removed and installed indoors, for safety reasons. Load cables and the gas supply line are hidden in the concrete pad and power plant floor. The power plant is installed next to a parking lot that is accessible to the public, and cases of vandalism have occurred here in the past. 


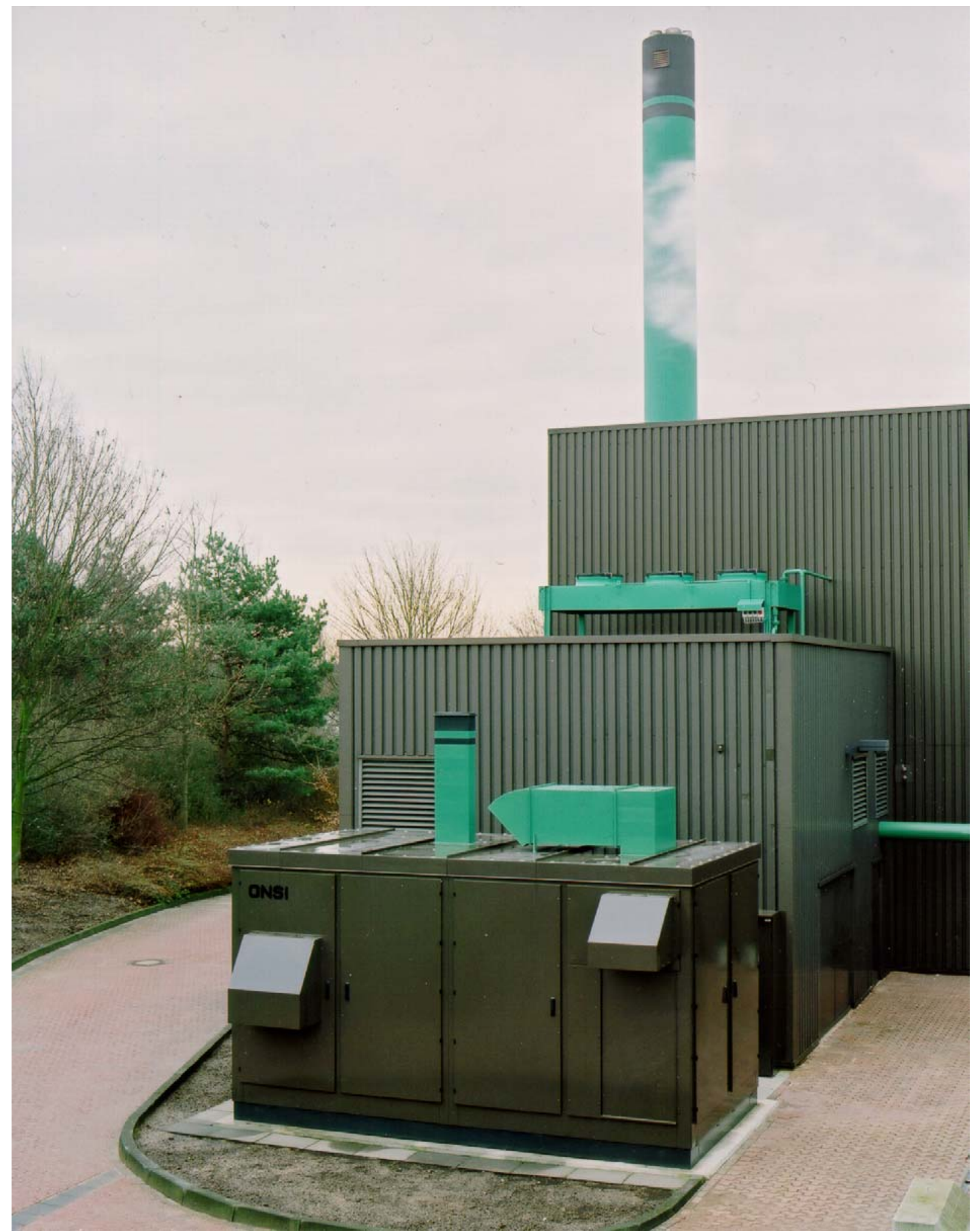

Site overview of the PC25C installation at the St.-Agnes-Hospital, Bocholt

The smaller building behind the fuel cell container holds the two gas engine cogeneration units, with the fuel cell's cooling module on top. The large building in the rear with the tall chimney is the hospital's boiler house. 


\section{Addresses}

Power Plant Owner / Operator; Site Address:

St.-Agnes-Hospital Bocholt

Barloer Weg 125

46397 Bocholt, GERMANY

Contact: Leo Most, Technical Director

Phone: +49-2871-202-023

Fax: $\quad+49-2871-202-600$

\section{Project Partners:}

Thyssengas $\mathrm{GmbH}$

Duisburger Str. 277

47166 Duisburg, GERMANY

Contact: Dr. Helmut Knappstein, New Technologies

Phone: +49-203-5555-2436

Fax: $\quad+49-203-5555-2653$

Bocholter Energie- und Wasserversorgung $\mathrm{GmbH}$ Hohenstaufenstr. 1

46395 Bocholt, GERMANY

Contact: Werner Vogel, Managing Director

Phone: +49-2871-954-110

Fax: $\quad+49-2871-954-300$

\section{Project Management:}

T.B.E. - Technische Beratung Energie $\mathrm{GmbH}$

Theodor-Heuss-Str. 3-5

47167 Duisburg, GERMANY

Contact: Knut Stahl, Project Management

Phone: +49-203-99546-18

Fax: $\quad+49-203-584347$

E-Mail: k.stahl@tbe.de 